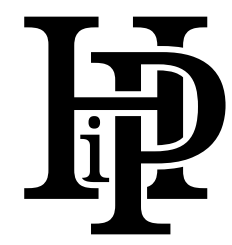

Historia i Polityka

No. 36(43)/2021, pp. 165-166

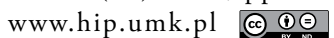

ISSN 1899-5160, e-ISSN 2391-7652

DOI: http://dx.doi.org/10.12775/HiP.2021.020

Kamila REZMER-PŁOTKA

Nicolaus Copernicus University, Faculty of Political Science and Security Studies, Toruń, Poland

\title{
Krzysztof Karczewski, In Trump We Trust. Stosunek Aleksandra Dugina do Donalda Trumpa i jego wizji Stanów Zjednoczonych Ameryki, Wydawnictwo Adam Marszałek, Toruń 2020, pp. 201
}

$\mathrm{D}$

onald Trump is undoubtedly a controversial figure, arousing extreme emotions. Therefore, it is not surprising that he became the object of interest of the wellknown Russian thinker Aleksandr Dugin. According to the peer-reviewed publication author, his thought is constantly evolving and surprises with ideological and political turns. As one such turn, the author sees a change in Dugin's attitude toward Americans since 2016, after Donald Trump was elected the President of the United States. The publication consists of an introduction, three substantive chapters, and a final chapter.

In the first chapter, the author lists the main program points during the political campaign preceding the 2016 elections. Moreover, he also focuses on Trump's visions of America and sorts them out. According to him, the following ideas were characteristic of the former president: conservative, nationalist, isolationist, protectionist, anti-globalist, populist, and antisystemic vision (pp. 23-25).
The next chapter analyzes Dugin's views on Trump and his vision mentioned in the book's previous part. The author shows the following stages of Dugin's attitude, from showing interest in the American presidential candidate, through the approval of his visions, to the open support for the US President.

In the final chapter, Dugin's vision of America and the role of Donald Trump were presented. The author points out how Aleksandr Dugin's attitude has evolved from an anti-American perspective and an undisguised dislike of everything American to "open condemnation of world governments” (pp. 123-124).

The analysis of Donald Trump's visions and his attitude toward state issues leaves a certain dissatisfaction. There was no extensive, more in-depth and thorough analysis of Trump's ideas about America and his policies. Certainly, it is difficult to describe on few pages the views of a man so charismatic and often full of contradictions in his judgments. Also, there was no 
methodological chapter in which the author would explain the selection of sources and how to systematize them. In addition, the publication unnecessarily provides forecasts and judgments - based purely on intuition - regarding the question of how Dugin would address particular issues, e.g., "I guess the Kremlin adviser would warmly welcome some points of the programme. This is how the Russian would agree to..." (p. 169). Even if one has a good analytical knowledge of a person's views, it is difficult to judge how they would address specific political movements and decisions. Especially since, as the author himself noted, over the years, Dugin's thought and his attitude toward America has changed drastically. Besides, there are terms and colloqui- alisms that should be avoided in scientific publications.

Noteworthy, however, is the fact that the author used foreign-language sources, specifically those of English and Russian provenance. He clearly distinguished the most important features of both Trump's and Dugin's political thinking. For this reason, the publication may be a good study for those who want to know, firstly, the basic assumptions of the former US president's policy, and secondly, the perception of his person and vision by the leading Russian philosopher, geopolitics expert and adviser to the Russian Federation. It is also an excellent reading proposal for students of international relations and political science. 